\title{
THE INFLUENCE OF CHEMICAL COMPOSITION OF TOUGH-TO-MACHINE STEELS ON GRINDING TECHNOLOGIES
}

\author{
Tanyana N. IVANOVA \\ Tchaikovsky Branch Perm National Research Polytechnic Institute \\ Federal State Budgetary Institution of Science \\ Aleksandr I. KORSHUNOV \\ Federal State Budgetary Institution of Science \\ Pavol BOŽEK \\ Slovak University of Technology
}

\begin{abstract}
:
The main purpose of processing of tough-to-machine materials is improving of cutting process of steels with different physicochemical properties and alloying by means of various chemical elements in combination with heat treatment. Producing of high quality surface layers depends on properties of material used to make details, that is why reasons of tough machining were identified: influence of chemical composition and resulting structure. The studies of grinding of tough-to-machine materials were undertaken by means of grinding wheels made from synthetic diamonds as they are most resistant and highly-productive. Based on the studies recommendations for using of characteristics of grinding wheels and tough-to machine steel grades are given. Research on heat processes during grinding allows us to determine patterns showing how cutting speed, detail motion speed, area and action period of contact influence temperature and speed of heat processes in surface layers as well as depth of heating. These patterns also give the chance to show interrelation between temperature and rate of heating and cooling. This gives an opportunity to predict state of structure of surface layer of details made of tough-to-machine steels under different machining conditions reasonably.
\end{abstract}

Key words: tough-to-machine materials, chemical composition, structure, grinding, grinding wheels

\section{INTRODUCTION}

Most of materials are constructional alloy steel with chemical addition agents and special tungsten, nickel, aluminium alloys are classified as tough-to-machine materials. Problems of their processing include complexity of getting treated surface with accuracy, roughness and physical and chemical state meeting the requirements of specified quality. Another problem is low productivity [1, $2,3,4,5,6,7,8,9,10,11,12,13,14,15,16,17,18,19$, $20,21,22,23,24,25,26]$.

\section{MAJOR PART}

Carried analysis of detail machining allows identification of causes of tough machining:

- chemical composition. Titanium, molybdenum, tungsten, vanadium and chromium elements have high activation energy dramatically increasing tensile strength of alloys based on these elements,

- low thermal conductivity coefficient resulting in increase in temperature by 5-7 times in area machined by standard grinding tools. The higher content of carbon and alloying elements is, the lower thermal conductivity coefficient is,

- low plasticity resulting in brittle fracture in cutting area,

- increased adhesion of abrasive to alloys material multiplying friction coefficient and resulting in tear-out of material, swarf sticking to cutting surface of tool that leads to its scaling,

- material structure: machinability as well as other properties - mechanical, technological, exploitation and special ones - is a function of chemical composition and structure. One of the main ways of structure regulation to provide necessary properties is heat treatment.

Titanium, molybdenum, tungsten, vanadium and chromium elements have high activation energy considerably increasing tensile strength of alloys based on these elements. An increasing of carbon content from 0.1 to $0.7 \%$ and injection of carbide forming alloying elements $(\mathrm{Mn}$, 
$\mathrm{Cr}, \mathrm{Mo}, \mathrm{W}, \mathrm{V}$ and etc.) abruptly reduces machinability of steels: specific output of grinding falls by $30 \%$ that can be explained by increasing of steel hardness and formation of "spesial" carbides: $\mathrm{Mn}_{3} \mathrm{C}, \mathrm{Cr}_{23} \mathrm{C}_{6}, \mathrm{Fe}_{3} \mathrm{Mo}_{3} \mathrm{C}, \mathrm{Fe}_{3} \mathrm{~W}_{3} \mathrm{C}$, $\mathrm{Mo}_{2} \mathrm{C}, \mathrm{VC}, \mathrm{WC}, \mathrm{TiC}$. Carbides are more resistant, less austenite-soluble and also have increased hardness and melting points.

When steels of carbide (martensite) kind are grinded, cutting power increases, specific output decreases with rising of the indicators characterizing elastic-plastic properties of steels. Resulting structure is highly alloyed tempered martensite with dispersive secondary "special" carbides and bigger primary carbides: $\mathrm{Me}_{6} \mathrm{C}, \mathrm{MeC}, \mathrm{Me}_{23} \mathrm{C}_{6}$ end $\mathrm{Me}_{3} \mathrm{C}$, where $\mathrm{Me}$ stands for carbide forming transition metals and iron. In addition, there are carbides of cementite kind $(\mathrm{Fe})_{3} \mathrm{C}$, special carbides $(\mathrm{Fe}, \mathrm{Cr})_{7} \mathrm{C}_{3},(\mathrm{Fe}, \mathrm{Cr})_{23} \mathrm{C}_{6}$, $(\mathrm{Fe}, \mathrm{W})_{6} \mathrm{C},(\mathrm{Fe}, \mathrm{V}) \mathrm{C}$ and interstitial phases that are present in alloy steel. "Special" carbides have crystal lattice that is different from cementite crystal lattice. They are hard, wear and temperature resisting, refractory materials which hardly melt in austenite when heated for quenching. Interstitial phases are related to intermediate phases. They have one of the simple compact lattices: body-centered cubic lattice, face-centered cubic lattice or face-centered close-packed lattice. Their occurrence in steels is inadmissible because they are not soluble in austenite when heated for hardening and they deplete austenite of alloying elements.

All types of carbides cause fast tear and wear of grinding wheel's abrasive grains. The tear and wear is entailed by abrupt temperature rising in grinding area, additional structural changes in surface layers of treated details and process efficiency reducing.
Annealed and normalized steels have perlite-sorbite structure, quenched steels have martensite-troostite structure. As for steels containing considerable quantities elements like $\mathrm{Mn}, \mathrm{Ni}, \mathrm{Cr}$ and etc., they have austenite structure. When steels with austenite structure are grinded, special output falls by $25 \%$ in comparison with martensite-troostite structure. It is explained by austenite having high plastic properties and impact strength.

Machinability of heat-resistant and corrosion-resistant steels is influenced not only by carbon which present in small quantities. The greatest effect is exerted by elements $\mathrm{Al}, \mathrm{Ti}, \mathrm{Si}$, less effect is caused by Mo, Co, Mn, Cr, W and $\mathrm{Ni}, \mathrm{Nb}, \mathrm{B}$ do not have any influence. Carbon, aluminium and titanium influence on worsening of machinability is explained by formation of dispersive phases based on this elements which harden solid solution of alloy. Carbon transforming during annealing or tempering of steel reduces its negative effect, because resulting intermetallic titanium-nickel compound causes hardening of the solid solution of alloy. Alloying of metals containing more than $2-3 \%$ of Mo, $\mathrm{W}$ also worsens the grinding machinability. Titanium abruptly worsens the processing if its content in alloy is five times greater than concentration of carbon. If there is no titanium in the alloy, nickel does not influence on processing thanks to lattice structure similar to gamma-iron and complete dissolution in material. Adding silicon in alloy dramatically reduces grinding machinability. Wear-and-tear resistant diamond grinding tools permit machining of all existing structural materials with minimal expenses, high accuracy of shapes and sizes and low roughness of machined surfaces.

Indices of tough-to-machine steels grinding process are adduced in Table 1.

Table 1

Criteria of grinding machinability of steel

\begin{tabular}{|c|c|c|c|c|c|c|c|c|c|}
\hline \multirow[t]{2}{*}{ Steel grade } & \multirow{2}{*}{ Thermal treatment } & \multirow{2}{*}{$\begin{array}{l}\text { Resis-tance } \\
\mathrm{T}, \mathrm{min}\end{array}$} & \multicolumn{2}{|c|}{$\begin{array}{l}\text { Grinding } \\
\text { strength }\end{array}$} & \multirow{2}{*}{$\begin{array}{c}\text { Wheel } \\
\text { wear q, } \\
\mathrm{mm}^{3} / \mathrm{min}\end{array}$} & \multirow{2}{*}{$\begin{array}{c}\text { Special } \\
\text { output, } \\
\text { u }\end{array}$} & \multirow{2}{*}{$\begin{array}{c}\text { Indices of } \\
\text { metal removal } \\
Q / Q_{T}\end{array}$} & \multirow{2}{*}{$\begin{array}{c}\text { Index of cutting } \\
\text { ability } K=Q / P_{y} \text {, } \\
\mathrm{mm}^{3} / \mathrm{min} N\end{array}$} & \multirow{2}{*}{$\begin{array}{l}\text { Rough-ness } \\
\text { Ra, microns }\end{array}$} \\
\hline & & & $P_{y}, N$ & $P_{z}, N$ & & & & & \\
\hline $1045(45)$ & Natural steel & 85 & 450 & 300 & 18 & 78 & $0.95-0.98$ & 310 & 0.60 \\
\hline $1045(45)$ & Quenched HRC 54-60 & 45 & 850 & 390 & 25 & 55 & $0.90-0.95$ & 165 & 0.38 \\
\hline 3415 (12XH3A) & $\begin{array}{l}\text { Quenched and case- } \\
\text { hardened HRC 56-62 }\end{array}$ & 45 & 950 & 320 & 30 & 47 & $0.90-0.95$ & 150 & 0.35 \\
\hline AISI 420 (40X13) & Natural steel & 15 & 780 & 390 & 80 & 18 & 0.90 & 186 & 0.80 \\
\hline 01 T31507 (ХВГ) & Quenched HRC 58-63 & 35 & 950 & 300 & 40 & 35 & $0.90-0.95$ & 147 & 0.32 \\
\hline $\begin{array}{c}\text { 35HGSA (35ХГСА) } \\
\text { Alloy steel } \\
\text { C: } 0.9-1.5 \%\end{array}$ & & & & & & & & & \\
\hline $\begin{array}{c}\text { Si: } 1.1-1.4 \% \\
\text { Mn: } 0.8-0.11 \% \\
\text { Cr: } 0.9-1.2 \% \\
\text { N: } 0.35 \%\end{array}$ & Quenched HRC 35 & 12 & 670 & 480 & 230 & 30 & $0.8-0.9$ & 23 & 0.5 \\
\hline $420(20 \times 13)$ & Quenched HRC 52-54 & 15 & 630 & 420 & 350 & 22 & 0.7 & 92 & 0.36 \\
\hline $\begin{array}{l}\text { AISI } 420 \text { (40X13) } \\
\text { R9F5 (P9Ф5) }\end{array}$ & Quenched HRC 52-54 & 12 & 650 & 510 & 370 & 18 & 0.63 & 90 & 0.32 \\
\hline High-speed steel & & & & & & & & & \\
\hline $\begin{array}{c}\text { C: } 1.4-1.5 \% \\
\text { Si: } 0.5 \% \\
\text { Mn: } 0.4 \%\end{array}$ & Quenched HRC 62-64 & 8 & 162 & 420 & 430 & 10 & 0.12 & 13 & 0.28 \\
\hline 301 (12X18H9) & Quenched & 10 & 670 & 510 & 400 & 15 & 0.53 & 60 & 0.32 \\
\hline
\end{tabular}


The grinding was done under the next operating conditions: grinding wheel speed uw $=35$ meters per second, detail's speed $u d=2.8$ meters per minute, the depth of grinding $\mathrm{t}=0.1 \mathrm{~mm}$. Cooling was done by means of solution containing $1.5 \%$ of cutting oil INKAM-1, which includes sulfur-containing or chlorine-containing oil additives.

Steel grades in Table 1 are placed according to worsening of machinability by dint of resistance criterion. The worsening of grinding machinability of metals is explained by increasing of strength properties of metal and presence of solid carbides resulting into intensive wear of blade edge and etc. For example, high viscosity of austenite steels and solid vanadium carbides in steel S12-1-4 (P9V5) abruptly increase wear and blunting of grinding wheel forming adhered particles of metal to cutting tips.

With worsening of steels machinability, increase of cutting strength is observed, wear of grinding wheel intensifies too. As for specific output, it decreases (provided each steel grade is grinded by grinding wheel with optimal characteristic) and so does removal of metal (real grinding depth becomes considerably less than the one defined by wheel-head movement because of wear and elastic compressions of the system). Index of cutting ability $\mathrm{K}$ decreases too. The harder steel is, the lower the roughness height is undependently from steel machinability.

Components of cutting force are of small value when steel AISI 420 is grinded. As for index of cutting ability, it is greater than the indices of steel 1045 and steel 3415. Based on these indices, steel AISI 420 can be classified as easy-to-machine steel. However, it is well-known that this steel is tougher to machine than steel 1045 . Estimate by dint of resistance criterion, wear and specific output shows that steel AISI 420 is $15-30 \%$ tougher to machine than steel 1045.

When workpieces made of corrosion-resistant steels are grinded, abrasive grains get blunt 3-4 times more than workpieces of carbon steel or low-alloy steel. For instance, the diameter of grain worn places increased to 8 microns while steel 1045 had been grinded for 20 minutes, and when steel 301 was grinded for 6 minutes to 13 microns. While grinding by means of wheels made of synthetic diamonds and cubic boron nitride, their consumption rate was observed to be considerable (more than $18 \mathrm{mg} / \mathrm{l}$ ), with super-hard material consumption rate increasing when passing from martensite to austenite steels. To increase durability and resistance of grinding wheel chemical treatment of the wheel is carried out to create durable pellicle on contact surface which reduces friction between the instrument and detail to be machined [2].

Processes of heat formation and plastic yield developing in machining area directly influence physical-mechanical state of surface layer of details made of tough-to-machine steels during grinding. Metal layer to be removed during machining is exposed to intensive plastic yield with high unit pressure while it forms swarf. High speed and temperature conditions of deformation lead to main part of resulting heat remaining in deformed volume and warming it up greatly. This effect is intensified due to following grain of abrasive tool cutting in metal warmed-up by previous grains.

Using the results of measuring the grinding temperature on the surface of the detail, the temperature was calculated along the detail cross-section (Fig. 1). Material: steel 3415 $(12 \mathrm{XH3A})$, sample size $10 \times 15 \mathrm{~mm}$, surface temperature $520^{\circ} \mathrm{C}$, wheel speed $20 \mathrm{~m} / \mathrm{sec}$, detail motion speed 1.5 $\mathrm{m} / \mathrm{min}$. Peak depth of temperature penetration is $0.5 \mathrm{~mm}$. Heat content of surface layer drops during grinding with cooling. Considerable decrease in temperature of the source is observed. If coefficient B is high and detail motion speed is low, the temperature of machined surface drops. Use of lubricating-cooling fluid reduces heating rate and increases cooling rate both beyond and under the source.

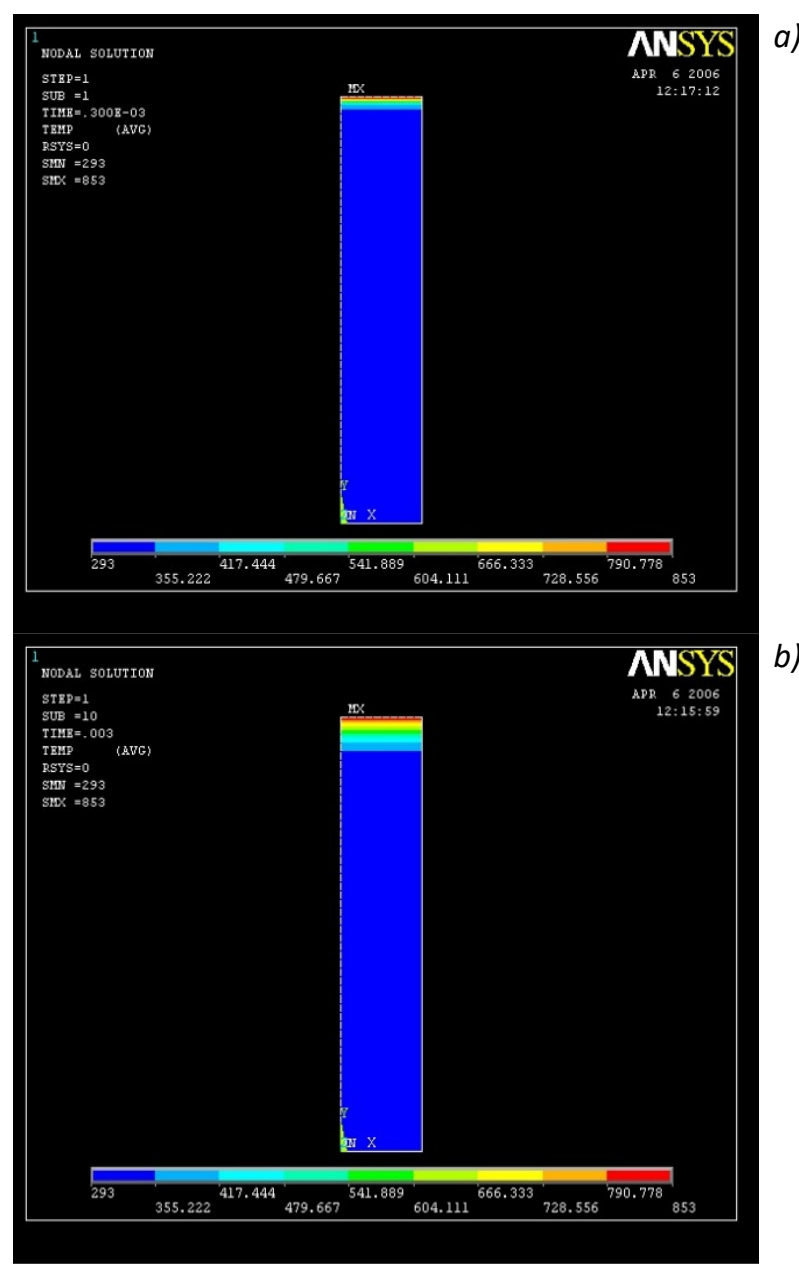

Fig. 1 Temperature distribution along the detail cross-section during grinding:

a) by tool with discontinuous cutting surface,

b) by tool with discontinuous cutting surface with lubricatingcooling fluid injected by flooding.

The temperature is given in Kelvins on the lower scale. pitch 0.0003

The cooling of heated surface occurs due to thermal conductivity of the sample with high speeds, upper layers cooling more intensively than lower ones. On some depth the process of heat accumulation slows down and cooling starts only when some time passed after heat source stopped working. As cooling rates of surface layers greatly exceed critical speed of quenching, austenitic-martensitic 
structure of secondary quenching may be formed. As for underlying layers with temperature being kept lower than $A_{c}$ points for some time, there are conditions for process of tempering with troostitic-martensitic structure formation. Under low intensity of heat source surface temperature does not reach $A_{c 1}$ points, secondary quenching does not occur and outside layers are tempered $[7,8]$. Distribution of occurrence depth of structurally changed layers depends on value of peak temperature on detail surface which in turn is governed by heat flow intensity and its operation time. Conducted research on influence of intensity of heat flow on structural changes demonstrated that two types of structural states can be obtained from alloy tool steels under action of thermal process of some intensity:

1. External secondary quenched layer of austenite-martensite lies on secondary tempered layer with troostitic-martensitic structure, gradually transferring in main structure. In this case sharp boundary between layers of secondary quenching and tempering should be mentioned.

2. Secondary tempered layer with structure of troostite or troostite-martensite gradually transfers in main structure.

Structural state of the first type is typical for thermal process with high intensity of heat source. As heat density of process decreases, the depth of changed layer drops due to reducing both secondary tempered layer and secondary quenched layer. Further heat flow density q decreasing leads to absence of structural transformations.

It is complicated to find out cooling and heating rates in thin surface layers of details practically, that is why the main research on influence of these factors on structural state of surface layer of samples was carried out basing on analytic calculation of heating and cooling rates and their comparison with results of microstructure analysis, microhardness measuring. Results of this research, given operation time of heat source is $\tau=6 \mathrm{~min}$, are demonstrated on Fig. 2.

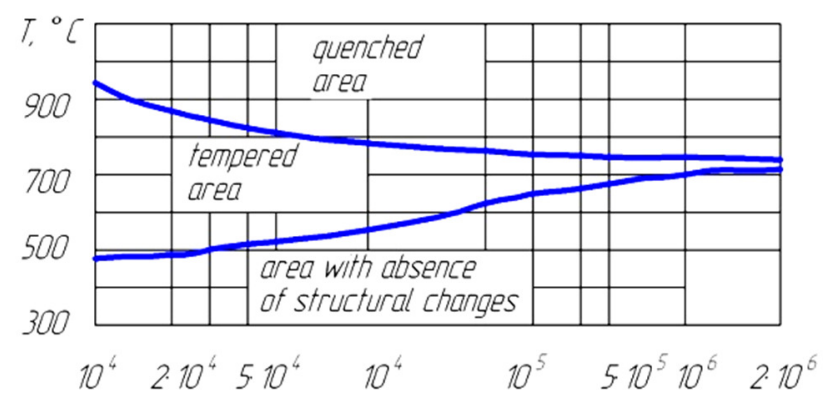

Fig. 2 Influence of temperature and speeds of thermal processes on the nature of structure transformations in surface layer

To find out possible structural changes during grinding we conducted analytical research on identification of temperature in cutting area depending on machining modes during different schemes of grinding. The results are given in Table 2.

Analytical calculations of maximal temperature of surface during grinding demonstrated that in case of intensive modes ( $u=0.20 \mathrm{~m} / \mathrm{min}$ and more) the temperature may exceed temperature of structural changes.

Increasing of cutting rate may considerably influence on grinding process because, on the one hand, process of metal removal intensifies. On the other hand, there can be changes of working conditions of every single bladeedge caused by speeding up sliding and deformation of metal. Also, there can be decrease in endurance of contact between blade-edge and surface to be machined. The most plain and clean scribe lines with high share of microcutting are observed when tough-to-machine materials are processed with high cutting speed and in case of employment of diamond or CBN tools. In addition, resulting scribe lines are characterized by less amount of metal flows, shelling and fiber breaking. Speeding up microcutting results into stable decrease of metal flows by sides of grinding scribe lines and more plain surface of scribe lines with more homogeneous grooves formed by microcutting.

Table 2

Maximal temperature depending on schemes of grinding and machining modes

\begin{tabular}{|c|c|c|c|c|c|c|c|}
\hline \multirow{2}{*}{$\begin{array}{l}\text { Motion diagram of } \\
\text { heat source }\end{array}$} & \multirow[b]{2}{*}{ Abrasive tool } & \multirow[b]{2}{*}{ Cooling } & \multirow{2}{*}{$\begin{array}{l}\text { Cutting power } \\
\text { (kW) }\end{array}$} & \multicolumn{3}{|c|}{ Grinding modes } & \multirow{2}{*}{$\begin{array}{c}\text { Temperature } \\
\mathrm{T}_{\max }{ }^{\circ} \mathrm{C}\end{array}$} \\
\hline & & & & $\begin{array}{c}U_{w} \\
\mathrm{~m} / \mathrm{s}\end{array}$ & $\begin{array}{c}\mathrm{Ud}_{\mathrm{d}} \\
\mathrm{m} / \mathrm{min}\end{array}$ & $\begin{array}{c}\mathrm{t} \\
\mathrm{mm}\end{array}$ & \\
\hline \multirow{4}{*}{ Along the detail } & & + & 0.18 & 25 & 0.05 & 0.3 & 280 \\
\hline & AC4MO13 & + & 0.22 & 25 & 0.1 & 0.4 & 310 \\
\hline & $100 / 80$ & + & 0.25 & 25 & 0.2 & 0.4 & 355 \\
\hline & & - & 0.63 & 25 & 0.3 & 0.4 & 510 \\
\hline \multirow{3}{*}{ Across the detail } & & + & 0.25 & 25 & 0.02 & 0.4 & 220 \\
\hline & AC2 MO4 & + & 0.48 & 25 & 0.05 & 0.3 & 340 \\
\hline & $125 / 1004$ & - & 0.96 & 25 & 0.15 & 0.4 & 490 \\
\hline
\end{tabular}


Table 3

Recommended characteristics of grinding wheels

\begin{tabular}{|c|c|c|c|c|c|c|}
\hline $\begin{array}{c}\text { Type } \\
\text { of grinding }\end{array}$ & $\begin{array}{l}\text { Steel to be ma- } \\
\text { chined }\end{array}$ & $\begin{array}{l}\text { Stock re- } \\
\text { moval ca- } \\
\text { pacity }\end{array}$ & $\begin{array}{l}\text { Roughness, } \\
\text { Ra, microns }\end{array}$ & $\begin{array}{l}\text { Abrasive grit } \\
\text { ISO 8486-86 } \\
\text { FEPA 42L }\end{array}$ & $\begin{array}{c}\text { Grain } \\
\text { ISO } \\
8486-86\end{array}$ & $\begin{array}{c}\text { Post } \\
\text { ISO } 8486-86\end{array}$ \\
\hline Semifinish machining & & $0.05-0.08$ & $1.0-0.32$ & $\begin{array}{c}\text { 160/125 - 80/63 } \\
\text { F12/F16 - F24/F30 }\end{array}$ & AC20 & $\begin{array}{l}\text { M1, M13, } \\
\text { ПM1, MK }\end{array}$ \\
\hline Finish machining & Natural steel & $0.01-0.05$ & $1.25-0.50$ & $\begin{array}{c}\text { 63/50 - M40/28 } \\
\text { F30/F36- } \\
\text { F70/F280/F360 }\end{array}$ & AC6 & M1, M10 \\
\hline Rough machining & & $0.08-0.15$ & $5-25$ & $\begin{array}{l}\text { 200/160 } \\
\text { F10/F12 }\end{array}$ & AC32 AC50 & $\begin{array}{c}\text { M13, M1, } \mathrm{MM} 1, \\
\mathrm{MK}\end{array}$ \\
\hline Semifinish machining & $\begin{array}{l}\text { Quenched } \\
\text { structional steel }\end{array}$ & $0.05-0.1$ & $2.5-1.0$ & $\begin{array}{l}\text { 160/125 - 100/80 } \\
\text { F12/F16 - F20/F24 }\end{array}$ & AC15 & $\begin{array}{c}\text { M13, M1, } \mathrm{MM} 1, \\
\mathrm{MK}\end{array}$ \\
\hline Finish machining & & $\begin{array}{c}0.005- \\
0.05\end{array}$ & $0.63-0.125$ & $\begin{array}{c}80 / 63-M 28 / 20 \\
F 24 / F 30-F 360 / F 400\end{array}$ & AC6 & M1, M10 \\
\hline Semifinish machining & Quenched alloy & $0.08-0.1$ & $0.63-0.5$ & $\begin{array}{l}\text { 160/125 } \\
\text { F12/F16 }\end{array}$ & AC15 & M013, MB1, M \\
\hline Finish machining & steel & $0.06-0.07$ & $0.32-0.16$ & $\begin{array}{c}80 / 63 \\
\text { F24/F30 }\end{array}$ & AC6 & MO4, MB1, M \\
\hline Finish machining & $\begin{array}{l}\text { High-speed } \\
\text { steel }\end{array}$ & $0.05-0.06$ & $0.43-0.31$ & $\begin{array}{l}100 / 80 \\
\text { F20/F24 }\end{array}$ & AC6 & $\begin{array}{l}\text { MO4, MO13, } \\
\text { MB1, M }\end{array}$ \\
\hline Finish machining & $\begin{array}{l}\text { Corrosion-re- } \\
\text { sistant steel }\end{array}$ & 0.025 & $0.32-0.29$ & $\begin{array}{c}100 / 80 \\
F 20 / F 24\end{array}$ & AC32 & MO4, MB1, M \\
\hline Finish machining & $\begin{array}{l}\text { Heat-resistant } \\
\text { steel }\end{array}$ & 0.03 & $0.32-0.29$ & $\begin{array}{l}100 / 80 \\
F 20 / F 24\end{array}$ & AC32 & MO4, MB1, M \\
\hline
\end{tabular}

\section{CONCLUSIONS}

Based on the researches, next recommendations for using of grinding wheels are given (Table 3 ).

Key factors defining rational machining conditions are durability of cutting surface, heat flows operating. They provide maximum possible metal softening of layer to be cut, saving high hardness and resistance of cutting instrument.

\section{REFERENCES}

[1] V.B. Dementyev and T.N. Ivanova. "Investigation of the surface layer structure of high-chromium and high-strength steels at the variation of the heating temperature". Materials Science Forum, vol. 870, pp. 431-436, 2016.

[2] T.N. Ivanova and A.M. Dolganov. "Up-to-date equipment in the technology of diamond face grinding of flat surfaces". Yekaterinburg: The Institute of Economics Press, Ural Branch of RAS, 2007.

[3] T.N. Ivanova. "Opportunities of abrasive tools in 21st century technology". Materials Science Forum "Advanced technologies of the XXI century", Odessa, pp. 113-118, 2013.

[4] T.N. Ivanova and F.Y. Svitkovsky. "Investigation of the regularities and the enhancement of the efficiency of the grinding process for components from hard-to-machine materials". Metal Treatment. Technology. Equipment, vol. 22, no. 1, pp. 22-24, 2004.

[5] T.N. Ivanova. "Investigation of the surface layer structure at grinding". Metal Treatment. Technology. Equipment. Tools, vol. 28, no. 3, pp. 30-32, 2005.

[6] T.N. Ivanova. "Investigation of machinability of hardto-machine steels at grinding". Natural Sciences and Technics, vol. 59, no. 3, pp.173-176, 2012.
[7] T.N. Ivanova and V.B. Dementyev. "Formation of the properties of the surface layer of components from hard-to-machine materials simultaneously at heating and cooling". Chemical Physics and Mesoscopy, vol. 15, no. 4, pp. 587-598, 2012.

[8] P. Božek and E. Pivarčiová. "Registration of Holographic Images Based on Integral Transformation". Computing and Informatics, vol. 31, no. 6, pp. 13691383, 2012.

[9] T.N. Ivanova and V.B. Dementyev. "Investigation of the physical-mechanical properties of steel $8 \mathrm{CrV}$ after high-speed thermal process". Chemical Physics and Mesoscopy, vol. 14, no. 4, pp. 7-18, 2012.

[10] I.P. Zakharenko. "Ultra-hard materials in tool production". Kiev: Higher School, 1985.

[11] V.P. Zverovshikov. "Dinamika centrobezhnoy obrabotki detaley diskretnym shlifovalnym materilom" [Dynamics of centrifugal processing of details by a discrete grinding material]. Monograph, Penza State University Press, 2005, p. 200.

[12] D.I. Volkov. "Theoretical model of the stress state of the surface layer of components at deep grinding". State Aviation Technological Academy, Vol. 15, no. 1, pp. 52-63, 2009.

[13] D.I. Volkov. "Finite-difference calculation of the temperature in belt grinding". Russian Engineering Research, vol. 32, no. 3, pp. 296-298, 2012.

[14] A.M. Kozlov. "Opredelenie parametrov rabochey poverhnosti abrazivnogo instrumenta na osnove modelirovaniya" [Model-based determination of the parameters of the working surface of an abrasive tool]. Proceedings of Institutions of Higher Education. Machine-building. 2005. № 1. pp. 51-55. 
[15] V.A. Nosenko. Technology of metal grinding. Stary Oskol: TNT, 2013.

[16] V.A. Nosenko. "Investigation of deep grinding of steel 30CrMnCNi2A". Proceedings of Volgograd State Technical University, no. 9, 2004, pp. 29-31.

[17] V.A. Nosenko. "Unidirectional and opposing deep grinding of titanium alloy with periodic wheel adjustment". Russian Engineering Research, vol. 30, no. 10, pp. 1016-1021, 2010.

[18] V.A. Nosenko. "Impregnation of abrasive tools with foaming agents". Russian Engineering Research, vol. 31, no. 11, pp. 1160-1163, 2011.

[19] D.V. Podzei. "Technologicheskie ostatochnye napryazheniya" [Technological residual stresses]. Monograph, Machine-building, 1973. p. 216.

[20] P. Božek and E. Pivarčiová. "Flexible manufacturing system with automatic control of product quality". Strojarstvo, vol. 55, no. 3, pp. 211-221, 2013.

[21] S.A. Popov, N.P. Malevsky and L.M. Tereshenko. "Almazno-abrazivnaya obrabotka metallov i tverdyh splavov" [Diamond-abrasive treatment of metals and hard alloys]. Monograph, Machine-building, 1977. p. 264.

[22] F.Y. Svitkovsky. "Nauchnye osnovy technologii glubinnogo shlifovaniya detaley iz trudnoobrabatyvaemyh materrialov" [Scientific principles of the technology of deep grinding of components from hardto-machine materials]. In Technological Sciences and Industry Restructuring Problems, 2003. p. 610.

[23] L.V. Khudobin and M.A. Belov. Grinding of work pieces from corrosion-resistant steels with the use of lubricoolants. Saratov: University Press, 1989.

[24] G.H. Yusupov, S.A. Kolegov and Y.T. Pusyreva. Effective diamond grinding. Stary Oskol: TNT, 2014.

[25] P.I. Yasheritsyn and A.N. Martynov. Finishing of metals in machine-building. Minsk: Higher School, 1983.

[26] E.M. Trent. Metal cutting. London: Butterworth, 1990.

Assoc. prof. Tanyana N. Ivanova, DSc.

Tchaikovsky Branch Perm National Research Polytechnic Institute

617764, Lenin st., 73, Tchaikovsky, Russia

Federal State Budgetary Institution of Science

Udmurt Federal Research Center of the Ural Branch

of the Russian Academy of Sciences

426067, T. Baramzinoy str., 34, Izhevsk, Russia

Prof. Aleksandr I. Korshunov, DSc.,

2Federal State Budgetary Institution of Science

Udmurt Federal Research Center of the Ural Branch

of the Russian Academy of Sciences

426067, T. Baramzinoy str., 34, Izhevsk, Russia

Prof. Ing. Pavol Božek, CSc.

Slovak University of Technology,

Faculty of Materials Science and Technology

J. Bottu 25, 91724 Trnava, Slovakia 